Petra Partlova,

Ph.D., Institute of Technology and Business in Ceske Budejovice, Czech Republic

ORCID ID, 0000-0003-2404-6073

email:partlova@mail.vstecb.cz

Jarmila Strakova,

D.Sc, Institute of Technology and Business in Ceske Budejovice, Czech Republic

(iD) ORCID ID, 0000-0002-3048-3467

email: strakova@mail.vstecb.cz

Jan Vachal,

Ph.D., Professor, Institute of Technology and Business in Ceske Budejovice, Czech Republic

ORCID ID, 0000-0003-0627-1517

email: vachal@mail.vstecb.cz

Frantisek Pollak

D.Sc, Institute of Technology and Business in Ceske Budejovice, Czech Republic

ORCID ID, 0000-0001-6346-8629

email: frantisek.pollak@mail.vstecb.cz

Jan Dobrovic,

D.Sc, Institute of Technology and Business in Ceske Budejovice, Czech Republic

ORCID ID, 0000-0002-0637-106X

email: 24574@mail.vstecb.cz

Correspondence author: partlova@mail.vstecb.cz

\title{
MANAGEMENT OF INNOVATION OF THE ECONOMIC POTENTIAL OF THE RURAL ENTERPRISES
}

Abstract. The analysis and management of innovation of the economic potential of the rural enterprises are currently the limiting factors of the stability and development of the enterprises; on the other hand, it is a condition for maintaining rural viability. Innovation is a catalyst for the growth of the enterprises, both within their internal environment and in the rural areas and the settlements established in such areas. Only the interconnection of the two levels of innovation (corporate and territorial) ensures stability and profitability for the enterprise. The paper focuses on the latter-mentioned part of innovation, both in terms of the methodology and research. The method for determining the innovative economic potential of rural settlements is presented in the paper, defined as the existential and development base for different enterprises. In relation, the paper discusses the issue of quantification of the economic potential of the clusters. The data acquisition is based on secondary data of the LAGs of the South Bohemian Region and the data from Ekotoxa. All municipalities of Trebonsko LAG (Czech Republic) are included in the data collection. The method for clustering the municipalities by their specifics, is supposed to be the most important result of the research, together with defining the areas suitable for innovation processes. Four models - Economic Cluster, Social Cluster, Cluster of Infrastructure, and Cluster of Environment - are defined based on four groups of the variables (economic, social, infrastructure, and environmental). A municipality is classified into an appropriate group based on the group (pillar) in which the municipality scored the highest average order. The average order of the municipality in each pillar is calculated as well. The method is followed by a verified procedure for defining the business potential of the clusters. The stepwise backward regression method is used to define the index of progressivity of the economic structure, determining the socio-economic differentiation of the regions in the Czech Republic. Regarding both the methodological procedure and the analytical tool, it is possible to state their suitable choice; the research results are relevant, valid, and usable in practice. The activities with high economic and innovation potential in the tested area include transport services, availability of the services, municipal infrastructure, drinking water supply, the occurrence of water bodies, and the structure of the population.

Cite as: Partlova, P., Strakova, J., Vachal, J., Pollak, F \& Dobrovic, J. (2020). Management of Innovation of the Economic Potential of the Rural Enterprises. Marketing and Management of Innovations, 2, 340-353. 

Rural Enterprises

Keywords: municipality, economic potential, rural area, cluster, Stepwise backward regression, models, LAG of Trebonsko.

Introduction. There is agreement on the need for innovation processes in the business environment, both among the business managers and among the scientific community. The ability to innovate is an important resource for ensuring the sustainable success of an enterprise (Moon and Chang, 2015). However, the implementation of such a process into the rural environment, and the environment of the municipalities is widely discussed. This is compounded by the fact that currently, there is no valid definition of rural areas, supported by the legislation. The reason is the ambiguous and polarized space with the various rural regions characterized by different development potential (Friedmann, 1966; Christaller, 1933; Hirschman, 1959; Novotna et al., 2005; Perlín, 2010; Skala, 2017). Considering the proven existence of more types of rural areas, there is a certain paradox, as the policy of Czech rural areas development tends to alleviate the differences. However, in the case of allocating by the municipality size, the differences are accentuated in more ways. As an example, the Rural development program allowed submitting applications for the municipalities with a population of 500 and more. The IV axis of the LEADER supported the municipalities, with up to 25,000 inhabitants included in the local action groups. By Binek, if there has to be a definition of rural areas for the application of development instruments, such specification must be unambiguous given its use commonly related to the allocation of the public resources (Binek et al., 2012). The development of rural areas does not necessarily have to be related to the improvement of the current state. Development can also include activities and tools used to sustain the current state (Binek et al., 2009) and to stop a long-term decrease using removing unwanted differences.

Literature Review. In the case of rural development, there are different types of cooperation, formed in the EU to support the policy of European rural development (see also Woods, 2011). A well-functioning Local Action Group (LAG), striving for the maximum use of the potential of its territory, uses mainly networking and cooperation (Faludi, 2006; Putnam, 1995; Bosworth, 2016. It uses new approaches and procedures to guide the local development of the territory, and there are efforts to eliminate and alleviate the unwanted regional differences within the LAG (Coleman, 1988).

The Czech rural areas have to deal with several issues. After 1989, there was a spatial disparity in the population distribution together with widening differences in the socioeconomic status of the regions (Blažek and Csank, 2007; Blazek and Netrdová, 2012; Jancak et al., 2008). Progressive activities, qualified workers, and university-educated inhabitants are concentrated in dynamically forming metropolitan areas. The rural areas remain sluggish (Ourednícek et al., 2011a, b; Hampl and Marada, 2016; Blazek, 1996). A lot of business activities disappear from rural settlements. The enterprises with craft and agricultural production disappear, or they move to large conurbations. There are no conditions for the creation of innovation potential. In rural areas, there is either a lack of regional specialization or a narrow specialization in the traditional sector. The focus on outdated technologies prevails (Tödtling, Trippl, 2005).

Similarly, there are insufficient services and facilities in rural areas. The frequency of public transport services decreases. There are limited job opportunities. The social and cultural activities of the inhabitants decline. However, it does not happen in all the regions and to the same extent (Perlín et al., 2010; Novak and Netrdová, 2011). One of the ways the inhabitants of rural areas comply with this situation is, for example, the outflow of young people and university-educated people away from the territory, which contributes to the aging of the rural population (Ouředniček et al., 2011a, b; Kučerová and Kučera, 2009).

Identification of the key factors in the development of rural areas is important for proper targeting of development activities. In the theories of regional development, the factors are divided into exogenous and endogenous, which, however, are not fundamentally opposed in practice, they rather complement 

Rural Enterprises

each other. The exogenous approaches emphasize externally initiated development dependent on external incentives and interventions, primarily from the state. On the contrary, there are endogenous approaches, where the development is not possible to be achieved only by getting support from the state. The bottom-up approach is also necessary, which means that the development is dependent on local impulses and resources, initiative, and the active participation of the local/regional actors. These interdependent and mutually conditioned factors are different with a different impact on rural development (Bernard, 2010, 2011; Muhlinghaus \& Walty, 2001).

The exogenous factors include the geographic location of the municipality, its size, environment, and economic factors, closely related to the institutional factors (Pospech, 2014; Hoggart and Buller, 2016, Binek et al., 2009). The geographic location of a rural municipality predetermines its local development (Binek et al., 2009). The location of a rural municipality is important, concerning the nearest regional center (Hampl, 2005; Pospech, 2014). It is closely related to the conditional relationship between the transport accessibility and the development of a territory (Pospech, 2014; Svobodova et al., 2011). Municipality size is also an important factor. By Skala, the municipality size is a limiting factor for a territory development from the economic perspective, since smaller municipalities might not have sufficient financial resources to ensure the most important functions of a municipality and to achieve development objectives (Skala, 2017. The environmental factors are also considered the very important external factors of the development of the municipalities (Woods, 2005; Hoggart and Buller, 2016). The quality of rural life depends on the quality of the environment (Woods, 2005; Okuneviciute Neverauskiene, 2018). Natural rural environment often plays a significant role in people's will to move to the countryside, especially for young families. Svobodova et al., 2011; Binek et al., 2009 add that the quality of the environment can enhance the residential and recreational function of the rural areas. The municipalities at the unfavourable location and with unsuitable size may use their natural potential for their development (Hoggart and Buller, 2016). The environment represents a potential for the development of tourism, and it is a significant financial driver for the municipality. In terms of the innovation processes related to the exogenous factors, they are difficult to be implemented, with a few exceptions.

The important endogenous factors include the quality and extent of infrastructure in the municipality (Marada and Kveton, 2016). Infrastructure has an influence on commuting to work and school as well as in everyday life. Besides transport and technical infrastructure, Svobodova (2009) mentions other development factors, which are the civic amenities of municipalities and access to services. For Binek et al. (2009), the facilities and offer of services in a municipality represent important internal development factors. Insufficient infrastructure and facilities can affect the quality of life of local inhabitants. Infrastructure and facilities are related to the municipality size (Svobodova, 2009). These relations are described as linear, since the bigger a municipality is, the better the facilities and infrastructure it has. Also, such municipalities are considered attractive with adequate financial possibilities for their further development and improvement (Bernard, 2011).

In terms of innovation of the production function of the territory, it is recommended to choose endogenous development directions for the small and medium-sized enterprises in rural areas (Vaishar et al., 2013), use the specifics of regions, and ensure their continuous innovation by the needs of the regions and the SMEs (Van der Ploeg et al., 2000; Muilu et al., 2004; Marsden and Sonnino, 2008). The ability to innovate is an important resource for ensuring the sustainable success of society (Moon and Chang, 2015).

Methodology and research methods. The main data sources were secondary data from the South Bohemian region LAGs obtained from Ekotoxa. The data collection included all the municipalities of Trebonsko LAG, which is 61 municipalities except for the towns with the population over 25 thousand, which means that Trebonsko LAG can contain all the municipalities. The data were divided into four pillars - economic, social, infrastructure and institutional, and environmental. There were four indicators selected 

Rural Enterprises

within the economic pillar, seven indicators in the social pillar, eleven indicators in the infrastructure pillar, and seven indicators in the environmental pillar.

1. Municipalities classification by individual clusters

Subsequently, the clustering of the municipalities was carried out, and four models were created - the economic cluster, the social cluster, the infrastructure cluster, and the environmental cluster, according to four groups of variables (economic, social, infrastructure, and environmental). Each municipality is classified into a group according to which group (pillar) it scored the highest average ranking in. In each pillar, an average ranking of each municipality is calculated, and subsequently, a relevant group (pillar with the best average ranking) is found.

2. Defining the business potential of clusters

In the next stage, the clusters (pillars) are analyzed using Stepwise backward regression in terms of their business potential. To analyze the business potential of the rural areas in the clusters, the progressivity index of the economic structure is identified as decisive. This index fundamentally determines the socio-economic differentiation of the regions in the Czech Republic. Each cluster is analyzed using stepwise backward regression. As a result, the significant variables affecting the business potential of each cluster are found (see Tables 1 and 2).

The algorithm of this method is that its application enables us to determine the explanatory variables into the explanatory variable of the resulting model of regression function y as follows: first, all explanatory variables are included in the Lm model. In the following steps, the variable with the largest $p$-value (statistically the least significant variable) is removed. This is carried out until an optimal regression model is found (Hocking, 1976; Christensen, 2002).

Before the research was initiated, two fundamental research questions were formulated. The first one proposes a procedure that would allow aggregate the rural areas and settlements (municipalities) into one of the pillars based on their specificities. The second research question is aimed at defining the business potential of clusters.

The unifying attribute of both research issues is to create a method that would enable the specification of the innovation activities for the cluster, and the pillar. A follow-up requirement, fundamental from the financial and corporate point of view, is the possibility to predict the benefits of different investment innovation activities in the enterprise in the mutual and variant combinations.

\section{Results.}

Classification of municipalities into clusters by analyzing groups.

Searching for a structure and relations in the objects is addressed by classification methods of multivariate statistical analysis. Classification methods are the procedures, whose application enables them to arrange a disordered group of the objects into several intrinsically homogeneous classes and clusters (cluster analysis CLA). The cluster analysis is one of the methods that deal with investigating the similarity of multidimensional objects (i.e., the objects with a large number of variables) and their classification into classes and clusters. It is useful, especially if the objects naturally tend to group.

Using the Cluster analysis, four clusters of municipalities are created - economic, social, infrastructure, and environmental according to four groups of variables (economic, social, infrastructure, and environment) so that each cluster contains the municipalities, making a difference in the area. Each municipality is included in a specific cluster according to which group (pillar) it scored the highest average ranking. This means that the municipality ranking is calculated in each variable, and then the average ranking of the municipality in each pillar is calculated. The average is calculated using the variables falling under the pillar. The municipality is then assigned the cluster in which the municipality scored the highest average ranking from all four pillars (see Figure 1).

companies in the primary sector, a double share of economically active companies in the secondary sector, and three times the share of economically active companies in the tertiary sector. 
P., Partlova, J., Strakova, J., Vachal, F., Pollak, J., Dobrovic. Management of Innovation of the Economic Potential of the Rural Enterprises

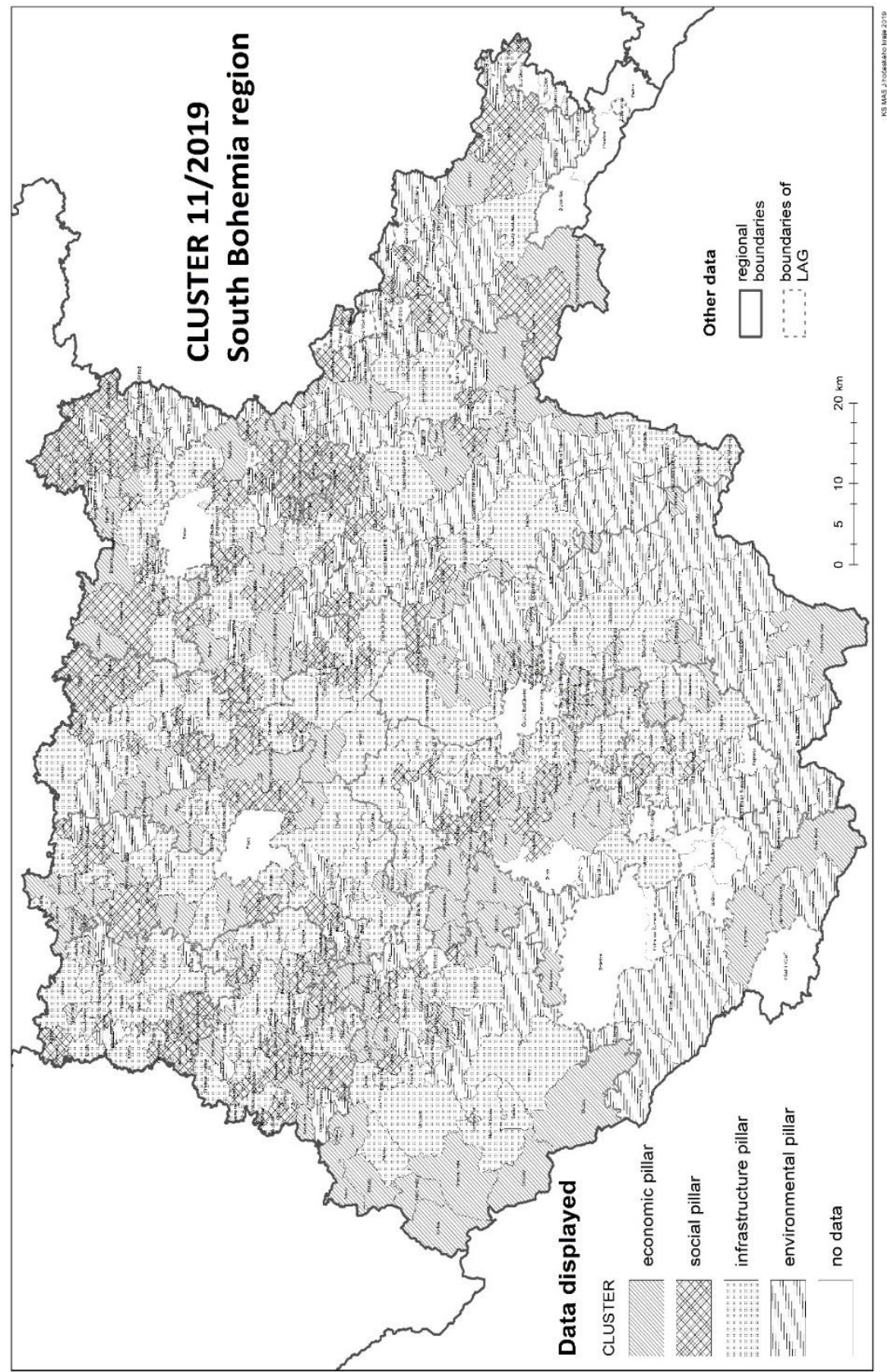

Figure 1. Map of South Bohemian municipalities, classified into economic, social, infrastructure and environmental cluster

Sources: developed by the authors 
The resulting map shows the classification of the municipalities in the pillars. For this paper, the classification of municipalities into the pillars in the case of Trebonsko LAG is described and explained (see Figure 2). The pillars are graphically differentiated (see the explanatory notes).

Characteristics of municipalities by individual pillars

The map of Trebonsko LAG (see Figure 2) shows the concentration of the municipalities identified in the economic pillar in the eastern part of the LAG, namely Címer, Kaclehy, Pribraz, and Hatín, and the town of Straz and Nezarkou. Generally, the inclusion of Címer is acceptable, as a large part of its income comes from the local quarry, which means there is some potential in the area. The municipality is located along an important road from Jindrichuv Hradec to Nova Bystrice, and it also has tourism potential.

In the past, the town of Straz nad Nezarkou was a location for some small enterprises, which, however, gradually ceased their activities. Its advantage is its location on an important backbone communication, and its economic potential is clear. In the case of other municipalities, their unambiguous predominance in this pillar is not found. Their predominance is rather related to the large regional center (Jindrichuv Hradec). Similarly, this applies to the remaining municipalities in this pillar on the western side of the LAG (Dunajovice, Mazelov, Smrzov), which are located near the town of Lisov, and whose potential in the economic pillar is easily assumed. The municipality of Hrachoviste cannot be unambiguously assessed in this respect.

Classification of municipalities into the social pillar is often related to the natives, staying in the municipalities. On the contrary, it is probably not related to the university-educated citizens.

In some municipalities (Zalsí, Mazice), there is a trend of using rural homesteads as recreational objects, and the economic potential of the municipalities is thus "ensured" by permanently settled residents (that is, those who did not migrate to larger residential centers for work), that is the natives. It is also considered in other municipalities.

It is assumed that practically all larger LAG towns, except for the town of Suchdol nad Luznici (see the Environmental pillar), are in the infrastructure pillar). Except for the municipality of Rapsach, it can be stated that the classification in this pillar is related to backbone communications in terms of both road and railway transport. The town of Kardasova Recice is situated on the 1st class road, connected to the completed D3 motorway so that its importance increased. There is also a railway station in the town.

The presence of Lasenice in the pillar is rather unexpected: the municipality is located along an important I/34 road. However, there is only a kindergarten; its civil amenities are standard. The WWTP was established rather recently. However, there is rather standard transport serviceability in the municipality, so that its classification is thus more or less justified.

The classification of the municipalities into the environmental pillar is related to the existence of Protected Landscape Areas (PLA, known as CHKOs in Czech) in the territory of the LAG. The distribution of the municipalities in the territory of the LAG is justified, even in the case of northern municipalities located outside the PLA (Borkovice, Zísov), which are situated in the area of the largest forest territories, called Borkovicka Blata. The presence of Suchdol nad Luznicí is considered justified since, despite the presence of production companies (EATON), the town and its parts are surrounded by larger forest areas and given the existence of water bodies that can be used for recreation, and the minimal stationary pollution emitters, there is real considerable potential in the town, not fully exploited.

Defining the economic potential of clusters

The classification of the municipalities in the South Bohemia region into the clusters was followed by defining and specifying the significant factors affecting the clusters in terms of the business potential. For such purpose, the progressivity index of the economic structure (INXPES) is used. The index is supposed to be a decisive territory index, fundamentally determining the socioeconomic differentiation of the regions and municipalities in the Czech Republic. It is a weighted sum of the share of economically active in the primary sector, double share of economically active companies in the secondary sector, and three times 
P., Partlova, J., Strakova, J., Vachal, F., Pollak, J., Dobrovic. Management of Innovation of the Economic Potential of the Rural Enterprises
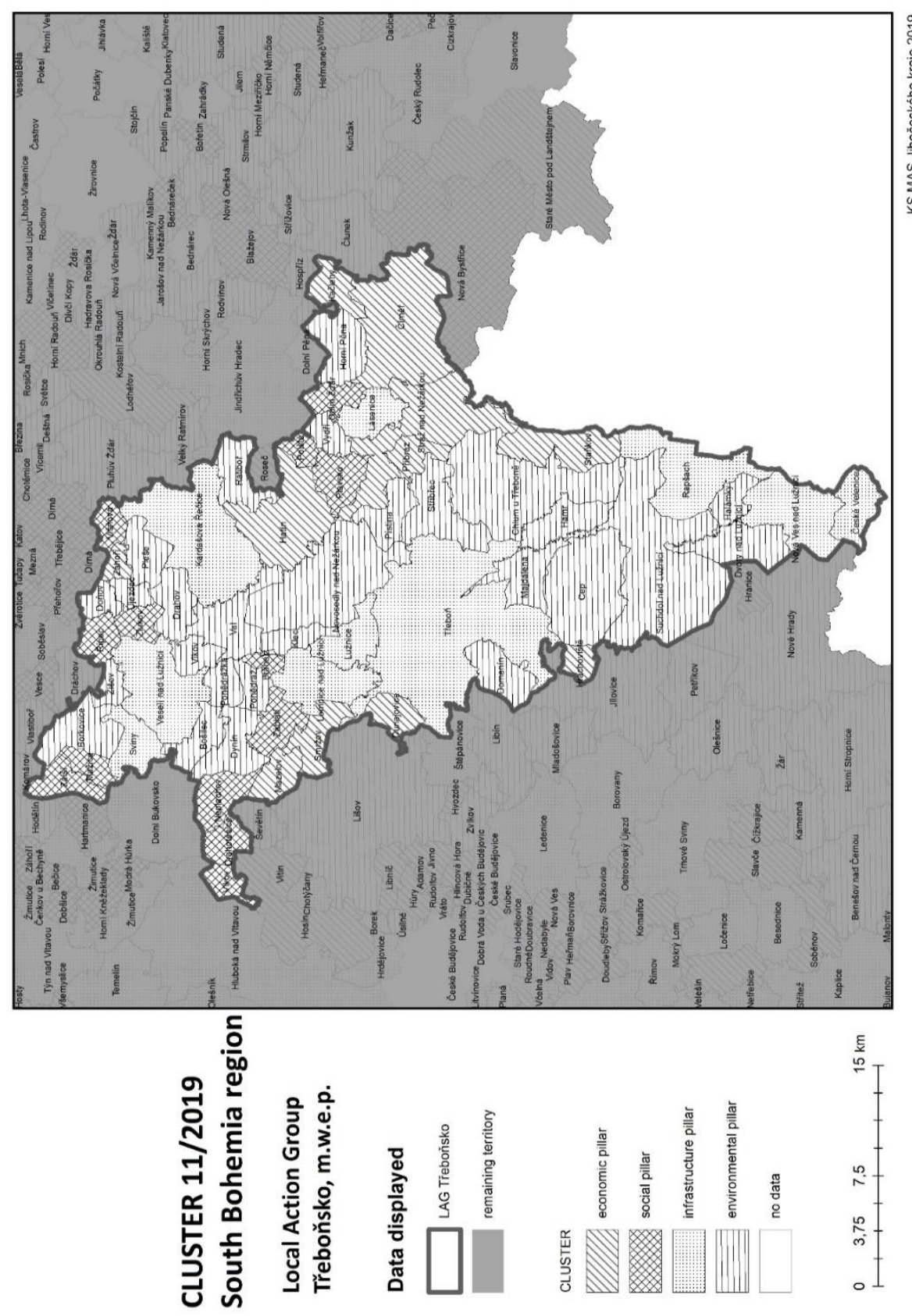

Figure 2. Map of municipalities in Trebonsko LAG, classified into economic, social, infrastructure and environmental clusters

Sources: developed by the authors 

Rural Enterprises

share of economically active companies in the tertiary sector.

Backward stepwise regression is used to test four clusters - models: Economic Cluster 1; Social Cluster 2; Infrastructure Cluster 3; Environmental Cluster 4

For each model, the following factors are analyzed: Values of significant variables; The tightness of multiple dependence within the tested model; Determination of the intensity of the tested factors (positive - + mark, negative - - mark), their influence on the test index, column Beta; Characteristics of the significant variables.

Due to the limited extent of the paper, the whole procedure is described through the analysis of Model Cluster 1 - Economic pillar. The description of the significant variables for Economic Cluster 1 is carried out on the example of Trebonsko LAG.

The results achieved by using the method described above for Cluster 1 revealed that the model Cluster 1 (see Table 1), that is, the economic cluster is influenced by four explanatory variables, as shown in Table 2. The resulting regression model for Cluster 1 is as follows:

Table 1. Economic Cluster 1 - input data

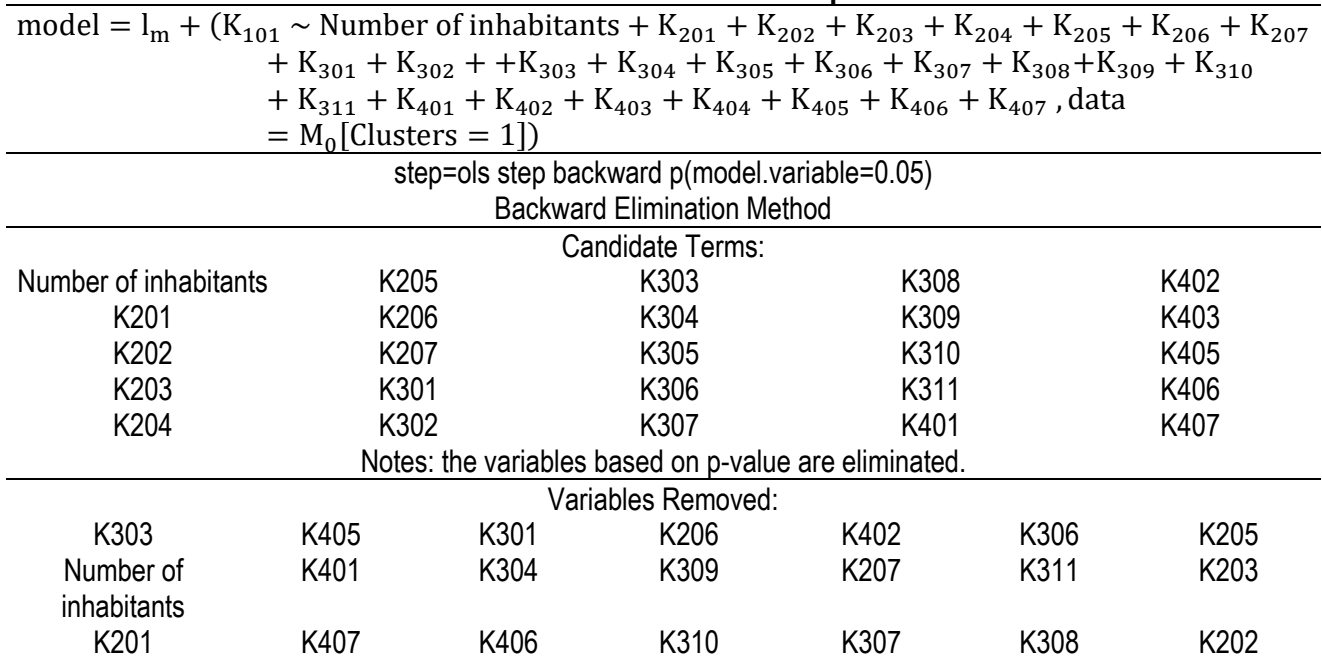

Notes: No more variables satisfy the condition of $p$-value $=0.05$

Legend: KOD - Economic pillar; K101 - Progressivity index of economic structure; K102 - Trend of economic structure progressivity index; K103 - Rate of business activity; K104 - Recreational potential in the recreational zone; KOD - Social pillar; K201 - Population density; K202 - Population aging (increase in the number of seniors-Ageing index trend); K203 -Trend of dependency ratio; K204 - Natives index of dependency ratio; K205 -Trend of increase in the population with university education K206 - Unemployment trend; K207 - Czech citizenship; KOD - Institutional and infrastructure pillar; K301 -Transport serviceability of the territory by public transport on working days; K302 - Transport serviceability of territory by public transport on Saturday; K303 - Accessibility of the territory from 1st class road and upper classes of roads; K304 - Accessibility of railway stations; K305 Inhabitants living in permanent dwellings connected to water, gas, and public sewerage systems; K306 - Kindergarten facilities K307 - Elementary school facilities;K308 - Accessibility of high schools finished with the maturita exams; K309 - Accessibility of senior living facilities; K310 - GP's surgeries for adults; K311 - Accessibility of hospitals and outpatient facilities; KOD Environmental pillar; K401 - Production capacity of land resources; K402 - Ecological fragmentation; K403 - Share of water bodies; K404 - Chemical condition of surface water; K405 - Trend of arable land; K406 - Zones of forest threat; K407 - Trend of specific territory emission from stationary sources

Sources: developed by the authors

The resulting form of the regression function is as follows: 
P., Partlova, J., Strakova, J., Vachal, F., Pollak, J., Dobrovic. Management of Innovation of the Economic Potential of the Rural Enterprises

$$
\hat{y}=2.541-0.003 x_{1}+0.004 x_{2}+0.001 x_{3}+0.005 x_{4}
$$

where:

$\hat{y}$ - selection (empirical) regression function - complete model

$\beta_{i}$ coefficients are marked as Estimates Beta for each indicator in the table.

$x_{1}=K 204 \quad$ Natives

$x_{2}=K 302$ Transport serviceability ensured by public transport on Saturdays

$x_{3}=K 305$ Citizens living in permanently occupied dwellings connected to water, gas, and public sewerage systems

$x_{4}=K 403 \quad$ Share of water bodies

Using the regression equation, the input data for the input factors $x_{1}-x_{4}$ are analysed. The results of the analysis are shown in Table 2.

Table 2. The resulting model for economic Cluster 1

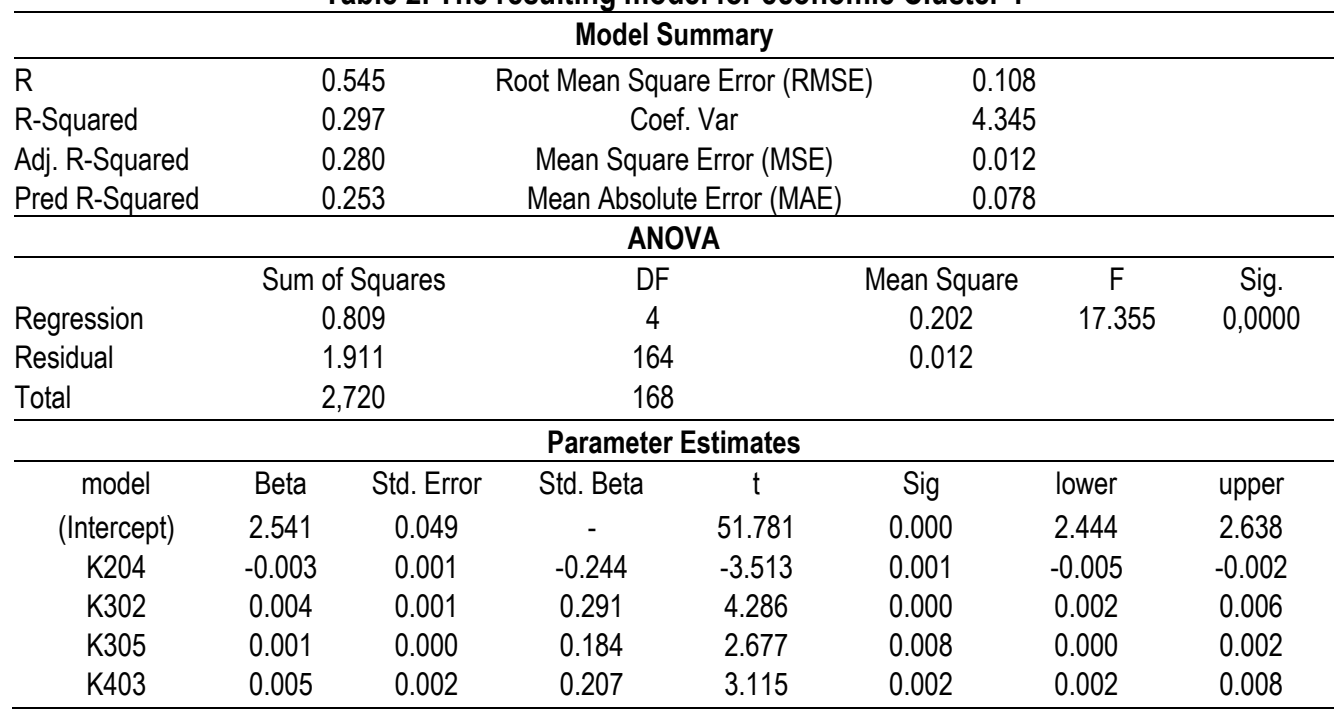

Sources: developed by the authors

The results in Table 2 show that the p-value is 0.000 (below 0.05); within the tested dataset, there are strong links between the tested variables.

The tightness of multiple dependencies of economic Cluster 1 is characterized by multiple correlation coefficient, which is a square root of R-squared adjusted (see Table 2).

$$
r_{B}=\sqrt{0,280}=0.52915026
$$

Based on the value of R-squared adjusted given in Table 2, the combined action of all the explanatory variables (Natives, Transport serviceability of the territory by public transport on Saturdays, Citizens living in permanent dwellings connected to water, gas, and public sewerage systems, and the Share of water bodies) explain $28 \%$ of the variability of the economic structure progressivity index variable in Cluster 1.

The results shown in Table 2 (column Beta) enable to identify the intensity of the variables influence on the business potential of South Bohemia region municipalities included in Cluster 1 . The tested Cluster 1 appeared to be positively influenced by the following factors: Transport serviceability of the territory by 

Rural Enterprises

public transport on Saturdays, Citizens living in permanent dwellings connected to water, gas, and public sewerage systems, and Share of water bodies. In contrast, the Natives appear to have a negative influence.

Description of the municipalities on the example of Trebonsko LAG included in economic Cluster 1 showed that the indicator Transport serviceability of the territory by public transport on Saturdays has a very positive influence in Straz and Címer with six transport lines on Saturdays. Transport serviceability of the territory by public transport on Saturdays was below average and none in the case of other municipalities. The factor of the Citizens living in permanent dwellings connected to water, gas, and public sewerage systems also reported a positive influence. The villages of Hatín and Smrzov show a very good level of technical infrastructure, on the other hand, Címer, Príbraz, and Straz nad Nezarkou showed a lower level.

The last factor having a positive influence on the business potential of the municipalities in the economic pillar was defined as the Share of water bodies. Compared with the Czech Republic average, most of the municipalities score above-average values. The share of water bodies significantly and positively affects the development of recreation; there is also some potential for the development of commercial and sport fishing, with favorable conditions for aquatic biosystems. The abundance of water bodies is directly linked to the natural resources potential in the territory. On the contrary, the negative influence identified for the Natives indicator is the most evident in Straz nad Nezarkou and Stankov. In these municipalities, the natives may have a negative influence on the development of the municipality as a result of supporting traditional values, decreasing the number of university-educated people, together with slight but permanent migration of the citizens to higher-category settlements.

Summary and recommendations. The presented research activities were carried out by the specified objectives. First objective was to propose a methodology for creating a procedure that would enable to aggregate the rural areas, or settlements - municipalities - according to their specifics, i. e. pillars. For this reason, four models were designed - economic, social, infrastructure, and environmental cluster according to four groups of variables (economic, social, infrastructure, and environment). The municipalities were then assigned to relevant models according to the highest value achieved in a relevant pillar. This procedure enabled the classification of municipalities according to individual clusters. The proposed procedure can be considered suitable for subsequent cluster aggregation of the municipalities of the predominance in a relevant pillar. This is essential both in terms of spatial planning of the individual municipalities' development and in terms of subsidy policy, i. e. the correct orientation of investment and other development instruments of a relevant municipality.

Another objective was focused on defining business potential of clusters with the application of backward stepwise regression method, which enables to analyse business potential. The paper presents the procedure of determining the economic structure progressivity index, which is considered a decisive differentiation index of the regions within the whole Czech Republic. In terms of the chosen analytical tool, it is possible to state its appropriateness, as the outputs obtained through its application provide relevant, valid, and applicable results.

The verified method of aggregation of the municipalities on the basis of their specifics and requirements is considered as fulfillment of the goals as set by the paper. The proposed procedure is considered a suitable tool for the categorization of innovative activities that are needed, assuming the favorable impacts on the economic potential of the rural areas, municipalities, and enterprises. The possibility to predict the impacts of financial investments in the innovation activities of the municipalities will enable the effective use of internal corporate resources in the synergy of rural innovation.

Although the fundamental research question was to find a methodology for municipality clustering, in terms of the practical application of the results, valuable findings of the territory in question were obtained, and some of them can be considered valid within the whole Czech Republic. These include: 

Rural Enterprises

- $\quad$ Classification of the municipalities into the clusters (pillars) using the cluster analysis. Clustering the municipalities is used to create four clusters of the municipalities - economic, social, infrastructure, and environmental by four groups of the variables (economic, social, infrastructure, and environment). The results are also processed graphically. The sensitivity of the data is proved, together with their explanatory value and the possibility of the practical application for the councils of the municipalities, the superordinate regional administrative bodies, and the activities of the LAG operating in the municipalities.

- $\quad$ Specification of the economic potential of the municipalities. This issue is not a very frequent topic in the Czech Republic and abroad. One of the four proposed indexes is used. As a decisive index for the differentiation of the regions within the national unit, the economic structure progressivity index is used. The backward stepwise regression method was appropriately chosen for the analysis of four models: economic, social, infrastructure, and environmental cluster model. The procedure of analyzing the tables (determining the value of significant variables, tightness of multiple dependencies within the tested model, the intensity of tested factors action, and characteristics of significant individual variables) is also considered suitable.

- A new practical finding is a fact that there is a close relationship between the variables in the case of tested Cluster 1. Furthermore, the analysis proved the joint effect of all the variables (Natives, Transport serviceability of the territory by public transport on Saturdays, the Citizens living in permanent dwellings connected to water, gas, and public sewerage, and the Share of water bodies), by which it is possible to influence about one-third of the economic potential in the municipalities.

- $\quad$ The economic potential is positively influenced by Transport serviceability of the territory by public transport on Saturdays, the Citizens living in permanent dwellings connected to water, gas, and public sewerage systems, and the Share of water bodies. The influence of the Natives factor is negative.

- The description of the municipalities in the Trebonsko LAG implies that there is a significant difference between the municipalities. The significant development includes the Transport serviceability of the territory by public transport, the Citizens living in permanent dwellings connected to water, gas, and public sewerage systems, and Technical infrastructure.

- In Trebonsko LAG, a crucial role is played by the water bodies. The region of South Bohemia, where the LAG is located, is environmental with the highest occurrence of the water bodies - mainly ponds, rivers, artificial reservoirs, and wetlands with peat deposits. The value of such aquatic biosystems is extraordinary; Trebonsko is a world-recognized biosphere bird sanctuary, reflected significantly in the assessment, and which also proves the suitability of the methodology and the analytical tool proposed.

Conclusions. By submitting the paper, the authors meant to contribute to the launching of a broad scientific discussion on the issue of analyzing, assessing, and practical application of the issue focused on determining the economic potential of rural areas with the subsequent use in the area to ensure the growth of value-creating processes of companies based on innovation activities. The results presented by the paper are neither considered to be final, nor the verified procedure is considered the only one possible; the form of the presentation is not considered special. Both in the Czech Republic and abroad, several studies and research are dealing with the issue; the research, however, showed that these are usually the solutions to sub-issues related to rural areas and settlement structure. The paper looks for a systematic and comprehensive approach in analyzing the territory to include all the most important rural areas and settlement structure. Without a stable potential base of the business sphere, i.e., the rural space, including the municipalities, it is not possible to assume the effective innovation processes in the business environment itself.

Author Contributions: conceptualization, P. P., J. S., J. V.; methodology, P. P.; validation, J. V., P.P., F. P.; formal analysis, J. D.; resources, P.P., J. S.; data curation, P.P.; writing-original draft preparation, P.P. 
Funding: This research was funded by the Technology Agency of the Czech Republic, a programme of ETA, project reg. No. TL01000349 - Stabilization, and development of SME in rural areas.

\section{References}

Bernard, J. (2010). Endogenní rozvojove potencialy malych obcí a místní samosprava. Sociologicke studie, 10(1).

Bernard, J. (2011). Endogenní rozvojove potencialy malych venkovskych obcí-obtízne hledaní a merení jejich vlivu. Sociologicky casopis/Czech Sociological Review, 47(04), 745-775. [Google Scholar]

Binek, J., Galvasova, I., Svobodova, H., Chabicovska, K., \& Holecek, J. (2012). Prístupy k posílení spoluprace a synergie ve venkovskych mikroregionech. [Google Scholar]

Binek, J., Svobodova, H., Holecek, J., Galvasova, I., \& Chabicovska, K. (2009). Synergie ve venkovskem prostoru: akteri a nastroje rozvoje venkova. Brno: GaREP. [Google Scholar]

Blazek, J. (1996). Meziregionalní rozdíly v Ceske republice v transformacním období. Geografie-Sborník Ceske geograficke spolecnosti, (4), 265-277. [Google Scholar]

Blazek, J., \& Csank, P. (2007). Nova faze regionalního rozvoje v CR?. Sociologicky casopis/Czech Sociological Review, 43(5), 945-966. [Google Scholar]

Blazek, J., \& Netrdova, P. (2012). Regional unemployment impacts of the global financial crisis in the new member states of the EU in Central and Eastern Europe. European Urban and Regional Studies, 19(1), 42-61. [Google Scholar] [CrossRef]

Bosworth, G., Annibal, I., Carroll, T., Price, L., Sellick, J., \& Shepherd, J. (2016). Empowering Local Action through NeoEndogenous Development; The Case of LEADER in England. Sociologia Ruralis, 56(3), 427-449. [Google Scholar] [CrossRef]

Christaller, W. (1933). Die zentralen Orte in Suddeutschland (the central places in southern Germany). Jena: Gustav Fischer.

Christensen, R. (2002). Plane answers to complex questions (Vol. 35, No. 1). New York: Springer. [Google Scholar]

Coleman, J. S. (1988). Social capital in the creation of human capital. American journal of sociology, 94, S95-S120. [Google Scholar] [CrossRef]

Faludi, A. (2006). From European spatial development to territorial cohesion policy. Regional Studies, 40(6), 667-678. [Google Scholar] [CrossRef]

Friedmann, J. (1966). Regional development policy: a case study of Venezuela (No. HT395. V4 F7). [Google Scholar]

Hampl, M. (2005): Geograficka organizace spolecnosti v Ceske republice: transformacní procesy a jejich obecny kontext. Univerzita Karlova v Praze, Prírodovedecka fakulta, Katedra socialní geografie a regionalního rozvoje, Praha. Retrieved from https://www.natur.cuni.cz/geografie/socialni-geografie-a-regionalni-rozvoj/other/files/hampl-geograficka-organizace

Hampl, M., \& Marada, M. (2016). Metropolizace a regionalní vyvoj v Cesku v transformacním období (Metropolization and regional development in Czech Republic during the transformation period-in Czech). Geografie, 121(4), 566-590. [Google Scholar] Hirschman, A. O. (1959). The Strategy of Economic Development. Yale University Press, New Haven. [Google Scholar] Hocking, R. R. (1976). A Biometrics invited paper. The analysis and selection of variables in linear regression. Biometrics, 32(1), 1-49. [Google Scholar] [CrossRef]

Hoggart, K., Buller, H. (2016): Rural development. Routledge, New York. [Google Scholar]

Jancak, V., Havlícek, T., Chromy, P., \& Marada, M. (2008). Regional differentiation of selected conditions for the development of human and social capital in Czechia. Geografie. Sbornik Ceske geograficke spolecnosti, 113(3), 269-284. [Google Scholar] Kóródi, M., Dávid, L.D. (2019). The Uniqueness Of The Hungarian Rural Tourism Supply. Journal of Tourism and Services, 10(19): 24-39. [CrossRef]

Kucerova, S., \& Kucera, Z. (2009). Vztah periferiality a vzdelavaní: Lze definovat periferní oblasti na zaklade vyvoje síte zakladních skol. Acta geographica Universitatis Comenianae, 52, 59-73. [Google Scholar]

Marada, M., \& Kveton, V. (2016). Transport supply and demand changes in relation to unemployment: Empirical evidence from the Czech Republic in a time of crisis. Tijdschrift voor economische en sociale geografie, 107(5), 611-627. [Google Scholar [CrossRef]

Marsden, T., \& Sonnino, R. (2008). Rural development and the regional state: Denying multifunctional agriculture in the UK. Journal of Rural Studies, 24(4), 422-431. [Google Scholar] [CrossRef]

Moon, H. Y., \& Chang, S. J. (2015). A Study on the Effect of Innovation Performance Through Business Innovation Activities and Techniques for the Small \& Medium Size Company. Journal of Korean Society for Quality Management, 43(2), 151-168. [Google Scholar] [CrossRef]

Muhlinghaus, S., \& Walty, S. (2001). Endogenous development in Swiss mountain communities. Mountain Research and Development, 21(3), 236-242. [Google Scholar] [CrossRef]

Muilu, T., Gilbert, A., Phimister, E., Shucksmith, M. (2004). The changing rural context. In Jentsch, B., Shucksmith, M. (Eds.): Young people in rural areas of Europe. The Arkleton Centre for Rural Development Research. Ashgate Publishing, 26-62.

Neverauskiene, L. O., \& Rakauskiene, O. G. (2018). Identification of employment increasing possibilities in the context of the

EU socioeconomic environment evaluation: The case of Lithuania. Economics \& Sociology, 11(4), 51. [Google Scholar] [CrossRef] 
Novak, J., \& Netrdova, P. (2011). Prostorove vzorce socialne-ekonomicke diferenciace obcí v Ceske republice. Czech Sociological Review, 47(4), 717-745. [Google Scholar]

Novotna, M. (2005). Problemy periferních oblastí, UK v Praze. PrF, Praha, KSGRR.

Ourednícek, M., \& Temelova, J. (2011). Nove socialne prostorove nerovnosti, lokalní rozvoj a kvalita zivota. Czech Sociological Review, 47(4), 625-631. $\quad$ Retrieved from http://urllab.cz/sites/default/files/ourednicek m. temelova j. 2011 nove socialne prostorove nerovnosti_lokalni_rozvoj_a kvalita zivota.pdf

Ourednícek, M., Spackova, P., \& Fertrova, M. (2011). Zmeny socialního prostredí a kvality zivota v depopulacních regionech Ceske republiky. Sociologicky casopis/Czech Sociological Review, 47(4), 777-804. [Google Scholar]

Perlín, R., Kucerova, S., \& Kucera, Z. (2010). Typologie venkovskeho prostoru Ceska. Geografie, 115(2), 161-187. [Google Scholar]

Pospech, P. (2014). Vynalezaní venkova $v$ CR po roce 1989. Centrum pro studium demokracie a kultury.

Putnam, R. D. (2000). Bowling alone: America's declining social capital. In Culture and politics (pp. 223-234). Palgrave Macmillan, New York. [Google Scholar] [CrossRef]

Skala, V. (2017). Vliv socialního kapitalu na rozvojovy potencial venkovskych obcí. Acta Politologica, 9(2), 40-56. [Google Scholar]

Svobodova, H. (2009). Development of rural regions-on example of hrotovicko microregion. New Economic Challenges, 234.

[Google Scholar]

Svobodova, H. (2011). Synergie ve venkovskem prostoru. GaREP, Brno.

Tödtling, F., \& Trippl, M. (2005). One size fits all?: Towards a differentiated regional innovation policy approach. Research policy, 34(8), 1203-1219. [Google Scholar] [CrossRef]

Vaishar, A., Stastna, M., Trnka, P., Dvorak, P., \& Zapletalova, J. (2013). South-Moravian rural borderland. European Countryside, 5(2), 115-132. [Google Scholar] [CrossRef]

Van der Ploeg, J. D., Renting, H., Brunori, G., Knickel, K., Mannion, J., Marsden, T., ... \& Ventura, F. (2000). Rural development: from practices and policies towards theory. Sociologia ruralis, 40(4), 391-408. [Google Scholar] [CrossRef]

Woods, M. (2004). Rural geography: Processes, responses and experiences in rural restructuring. Sage. [Google Scholar]

Woods, M. (2011). Rural. Taylor \& Francis Book, Routledge.

Петра Партлова,

Ph.D., Iнститут технологій та бізнесу в Чеське Будейовіце, Чеська Республіка

Ярміла Стракова

D.Sc, Інститут технологій та бізнесу в Чеське Будейовіце, Чеська Республіка

Ян Вачал,

Ph.D., профф., Iнститут технологій та бізнесу в Чеське-Будейовіце, Чеська Республіка

Франтишек Поллак,

D.Sc, Iнститут технологій та бізнесу в Чешке Будейовіце, Чеська Республіка

Ян Добрович,

D.Sc, Iнститут технологій та бізнесу в Чешке Будейовіце, Чеська Республіка

Управління економічним потенціалом інноваційного розвитку сільськогосподарських підприємств

Ця стаття узагальнює аргументи та контраргументи в межах наукової дискусії з питання управління економічним потенціалом інноваційного розвитку сільськогосподарських підприємств. Встановлено особливості управління економічним потенціалом сільськогосподарських підприємств. Визначено місце та значення сільськогосподарських підприємств для забезпечення життєдіяльності сільської місцевості. Розкрито економічну сутність інноваційної діяльності в економіці, визначено що інновації є каталізатором розвитку як внутрішнього так і зовнішнього середовищ підприємств, а також, загалом, населеного пункту. Встановлено, що взаємозв'язок між двома рівнями інновацій (корпоративним та територіальним) забезпечує стабільність та прибутковість підприємства. Основною метою проведеного дослідження є визначення впливу розвитку сільських територій на економічний потенціал інноваційного розвитку сільськогосподарських підприємств. Об'єктом дослідження обрано сільскогосподарські підприємства регіону Південної Чехії. Рівень розвитку сільських територій запропоновано оцінювати на основі чотирьох груп змінних: економічні, соціальні, інфрраструктурні та екологічні. Визначено індекс прогресивності економічної структури та соціально-економічної диференціації регіонів Чеської республіки за допомогою методу покрокової зворотної регресії. Виокремлено чотири кластери розвитку сільськогосподарських територій: економічний кластер, соціальний кластер, кластер інфраструктури, кластер навколишнього природного середовища. В статт представлено результати емпіричного аналізу, який дозволив встановити діловий потенціал кожного 3 кластерів та можливості інноваційного розвитку сільськогосподарських підприємств в межах кожного з кластерів. Обірунтовані ресурси та резерви підвищення конкурентоспроможності та можливості впровадження інноваційних проектів сільскогосподарськими підприємствами залежно від пріоритетних напрямків розвитку сільських територій. Отримані результати проведеного 
P., Partlova, J., Strakova, J., Vachal, F., Pollak, J., Dobrovic. Management of Innovation of the Economic Potential of the Rural Enterprises

дослідження можуть бути корисними для власників сільскогосподарських підприємств при визначені можливостей прогнозування їх сталого розвитку з врахуванням вказаного інструментарію та методів.

Ключові слова: економічний потенціал, сільськогосподарські території, кластер, покрокова зворотна регресія, моделі

Manuscript received: 30.11.2019

(C) The author(s) 2020. This article is published with open access at Sumy State University. 